\title{
Analyzing the Capacity of Iran Non-Oil Exports to the Region No. $2^{*}$ Countries
}

\author{
Kianoush Jamakoohi1" ${ }^{\#}$ Elham Alizadeh², Hossien Moghimi Esfandabadi ${ }^{3}$ \\ ${ }^{1}$ Allameh Tabataba'i University, Tehran, Iran \\ ${ }^{2}$ Islamic Azad University Central Tehran Branch, Tehran, Iran \\ ${ }^{3}$ Development and Economic Sociology, University of Islamic Azad, Tehran, Iran \\ Email: Kianoush.jamakoohi@yahoo.com
}

How to cite this paper: Jamakooh, K. Alizadeh, E. and Esfandabadi, H.M. (2019) Analyzing the Capacity of Iran Non-Oil Exports to the Region No. 2 Countries. iBusiness, 11, 57-65.

https://doi.org/10.4236/ib.2019.114006

Received: May 9, 2019

Accepted: December 3, 2019

Published: December 6, 2019

Copyright (c) 2019 by author(s) and Scientific Research Publishing Inc. This work is licensed under the Creative Commons Attribution International License (CC BY 4.0).

http://creativecommons.org/licenses/by/4.0/

\begin{abstract}
To create global interdependence and also to emerge of a global village is assumed to be one of the most important effects of the structural transformation in economy globalization phenomenon. With regard to the growing trend of this novel phenomenon and the necessity for a broad participation of countries in international arena depicted the role of countries in international competitiveness more effectively. This article reviews the capacity for Iran export (non-oil) to region No. 2, using the "gravity model" during the period 2011 to 2015. The estimated results indicated that Iran amongst countries in region No. 2 had the highest potential export to Iraq and the least potential allocated to Armenia. Moreover, the highest percentage of unused capacity of Iran belonged to Azerbaijan and the lowest unused capacity referred to Armenia.
\end{abstract}

\section{Keywords}

Export Capacity, Regions' Countries, Gravity Model

\section{Introduction}

Trade portrays an important role in the dynamism and countries economic growth. Most countries are anxious to expand trade with other countries and produce goods thanks to their comparative advantage in order to enlarge their *Iran shares land borders with eight countries and seven other countries neighboring with maritime borders. Therefore, we divided Iran's neighbors into four regions. Region 1 includes the countries of Kazakhstan and Turkmenistan, region 2 including Russia, Azerbaijan, Armenia, Turkey and Iraq, region 3 including Kuwait, UAE, Qatar, Bahrain and Saudi Arabia, the fourth region includes Afghanistan, Pakistan and Oman. In this study, we are looking to explore Iran's capacity for further production and export to countries in Region No. 2. 
economic growth [1]. One of the most important problems of developing countries is monocularity and their reliance on the exporting primary and raw materials, which has left negative effects in the economic, political, social and even cultural structures. Whereas a large portion of Iran foreign exchange earnings is obtained merely by issuing one item or more primary and raw materials, whenever they are exposed to external pressures they tended to be extremely delicate and fragile (at least in the long run). Obviously, in such circumstances, any abnormal fluctuations in the price of this commodity or the limited commodities that made up the main income sources would have a profound effect on their economic, political, social and even cultural structures [2]

The gravity model seeks to answer the question of why business relations are very strong among some countries. In order to answer this question, the variables in it (especially the gap variable and gross domestic product) are applied to highlight the causes of the development of international trade. Another advantage of this model is the business model test with availability and reliability of information, data controllability and the number of appropriate variables [3]

Gravity models are an appropriate tool for estimating trade potential and widely used in international trade to describe a bilateral trade flow.

In the international economy, these models allow us to estimate bilateral trade potential at specific times and at the same time the exporting and importing countries perspectives can be foreseen. In fact, in the framework of this model, existing barriers and constraints can be introduced into quantitative and qualitative variables and their impact on bilateral trade can be investigated [4]. Iran has trade exchanges with 100 countries, about $40 \%$ of which are the neighbored countries which, if we add services, surely more share of the volume of trade between Iran and neighboring countries will increase.

For Iran in recent years, Iraq has been one of the main export destinations and always been at the top of the list of 100 major countries of exporting destination. According to the ITC statistics in 2015, Iraq has been exported to more than $\$ 5.8$ billion and ranked second in Iran's export markets. Turkey is ranked seventh in the list of 100 exporting destinations countries, turkey non-oil exports products accounted for 3.18 percent of Iran's total export value. On the other hand, Armenia has imported \$ 3 billion and \$ 500 million from other Iranian neighbors, of which \$ 8.4 million of (including \$ 198 million in oil and gas) Armenia import referred to Iran market [5]. According to existing reports, Iran is the 15th largest exporter to Azerbaijan, the total amount of Azerbaijani exports in 2015 is $\$ 21.7$ billion, and the positive annual trade balance of $\$ 12.5$ billion indicated its high financial potential for imports from Iran. In 2015 Russia according to the same statistics, imported totally $\$ 177$ billion goods from the world. Its trade balance was approximately $\$ 156$ billion in 2015 . Based on the Customs of the Islamic Republic of Iran reports, the export of goods from Iran to Russia in 2015 was equivalent to $\$ 240$ million [6].

Currently, Iran domestic market facing a stagflation, which has a negative ef- 
fect on products competitiveness of in domestic and foreign markets, which ultimately restricts their sale within and outside Iran borders. It is necessary to diversify the country's economy and provide suitable solutions to reduce reliance on oil revenues and tend to non-oil exports spouting, which can lead to lower inflation, new job opportunities, growth of productive investment, and so on. Hence, law reform especially in foreign trade sector, attracting domestic and foreign investment, as well as helping to strengthen the competitiveness of national economies in the international arena, is urgent to increase the share of global trade [1]. Therefore, the present study has been carried out considering the importance of non-oil exports, getting out of the oil-dependent economy, the necessity to increase the GDP-based revenue and exit from the Stagflation Iran's non-oil export capacity to five neighboring countries was reviewed.

\section{Theoretical Literatures}

The Gravity Model was introduced by Tienbergen in 1963 [7] and developed by Linnman [8] Aitken [9]. In his article on gravity models, Matyas [10] states that this model plays an important role in empirical studies, especially in the field of business-cycle forecasting and useful for policy analysis Evenett and Keller [11] Finestra, Marcosen, and Rose [12] have extracted the gravity model from the Theoretical Model of Huckcher-O'Hallon, or new ideas of international tradel. Anderson [13] attempting to examine the theoretical basis of the gravity model, further it has been expanded in 1979 to examine the architecture of commerce in Canada after the country's trade with the United States which showed that comparison with trade in Canadian domestic provinces was increased more than the trade of Canadian border provinces with states of the United States. Therefore, there is still no general basis for the gravity model.

Although relatively few domestic studies have examined the factors affecting Iranian trade and the interrelationship between trade and other economic variables, a comprehensive study of the capacity and potential of exporting non-oil goods to countries in Region 2 has not been conducted using a gravity model, with the ability to justify the new and innovative aspect of research (Table 1).

\section{Methodology}

\subsection{Sample \& Data Selection}

In this study, the data covering the period 2005-2015 Iran's non-oil exports to five neighboring countries (Russia, Turkey, Armenia, Azerbaijan and Iraq) from Trade Map website and the Iranian Customs Organization were used. Data on gross domestic product from the World Bank website and the distance between Tehran and capital of the trading countries have been extracted from the Indo website.

\subsection{Model and Econometrics}

The gravity model that we take under consideration and use with variations has long been used [13]. 
Table 1. Summarizes the backgrounds of domestic and foreign research related to the topic.

\begin{tabular}{|c|c|c|c|}
\hline Researcher year & Subject & Main variables model & Results \\
\hline Linnman [8] & $\begin{array}{l}\text { Using Trading Streams of } 80 \text { Countries for } \\
\text { estimation of Bilateral Export and Import } \\
\text { functions Via the Gravity Model and the } \\
\text { explanation variables of the Exporter and } \\
\text { Importer }\end{array}$ & Gravity model & $\begin{array}{l}\text { The results showed that population growth increases } \\
\text { the ability to produce more for domestic consumption, } \\
\text { and as a result, imports were reduced; besides gap } \\
\text { variable is an important barrier for trade. }\end{array}$ \\
\hline Aitken [9] & $\begin{array}{l}\text { Investigating the AFTA agreement } \\
\text { formation based on bilateral trade flows } \\
\text { between members }\end{array}$ & Gravity model & $\begin{array}{l}\text { The results of this estimate indicate that integration has } \\
\text { increased the AFTA trade }\end{array}$ \\
\hline $\begin{array}{l}\text { Jim and others } \\
(1992)[14]\end{array}$ & $\begin{array}{l}\text { Effects of Uruguay-Argentina and } \\
\text { Uruguay-Brazil Bilateral } \\
\text { Trade Agreements using Gravity Model }\end{array}$ & Gravity model & $\begin{array}{l}\text { The results of this estimate indicate that the trade } \\
\text { potential estimated by the model for Uruguay trade with } \\
\text { Argentina and Brazil is significantly different from } \\
\text { reality. And this is due to the similar manufacturing } \\
\text { structure of these countries. In fact, these three countries } \\
\text { cannot cover exchange needs of each other, and as a } \\
\text { result, other countries have more business-oriented } \\
\text { relationships than their own trade relationship. }\end{array}$ \\
\hline $\begin{array}{l}\text { Rahman (2003) } \\
{[15]}\end{array}$ & Bangladesh Trade Assessment & Gravity model & $\begin{array}{l}\text { The estimates show Bangladesh trade is not } \\
\text { independent of the behavior of business partners (such } \\
\text { as the exchange rates determination and the tariffs) }\end{array}$ \\
\hline $\begin{array}{l}\text { Lamoty (2002) } \\
{[16]}\end{array}$ & $\begin{array}{l}\text { The study of trade potential between } \\
\text { Yugoslavia \& European Union }\end{array}$ & Gravity model & $\begin{array}{l}\text { The results showed that trade between Yugoslavia and } \\
\text { European Union could be increased by } 80 \% \text {. }\end{array}$ \\
\hline $\begin{array}{l}\text { Harati and Behrad } \\
\operatorname{Amin}(2015)[17]\end{array}$ & $\begin{array}{l}\text { A Study of the Factors Affecting Iran's } \\
\text { Export }\end{array}$ & Gravity model & $\begin{array}{l}\text { The results of the estimated models showed that Iran's } \\
\text { export could be explained by the significant portion of } \\
\text { factors included in the gravity model. Furthermore, the } \\
\text { results are different with respect to geography and their } \\
\text { level of development of business partners }\end{array}$ \\
\hline
\end{tabular}

The model form used is as follows:

$$
\begin{aligned}
L X_{i j t}= & \beta_{0}+\beta_{1} L G D P_{i t}+\beta_{2} L G D P_{j t}+\beta_{3} L P O P_{i t}+\beta_{4} L P O P_{j t}+\beta_{5} L D_{i j} \\
& +\beta_{6} L E_{i t}+\beta_{7} L E_{j t}+\beta_{8} C O S X_{i} M_{j}+\beta_{9} d_{1}+\beta_{10} d_{2}+U_{i j t}
\end{aligned}
$$

$L$ : logarithm operator;

$X_{i j i}:$ real export of the country $i$ (the exporter) to the $j$ country (the importer) at time $t$

$G D P_{i}$ and $G D P_{i}$ Income (gross domestic product) of the two countries $i$ and $j$; $P O P_{i}$ and $P O P$ : The population of both countries $i$ and $j$

$D_{i:}$ : The distance between the capital of Dukshor and $i j$;

$E_{j t}$ and $E_{i t}$ The real exchange rate of both countries $i$ and $j$.

Following these variables, a set of virtual variables will be added to explain other effects on mutual trade flow in the country as follows:

$d_{1}$ : The virtual variable of common border and $d_{2}$ is the virtual variables of the common religion, which, if there is a subscription between two countries, consider one and otherwise, zero.

$\operatorname{COS}_{i} M_{j}$ : Exports exact Index of country $i$ to $j$ country (similarity between exporting and importing countries) 


$$
\operatorname{COS}_{i} M_{j}=\frac{\sum_{k} X_{i k} \cdot M_{j k}}{\sqrt{\sum X_{i k}^{2} \sum M_{j k}^{2}}}
$$

\section{Analysis of Findings}

Analysis of findings:

According to theoretical foundations, we expect $\beta_{1}$ and $\beta_{2}$ to be positive. The sign $\beta_{3}$ and $\beta_{4}$ can be positive or negative. The $\beta_{5}$ sign should be negative, as expected. The sign $\beta_{7}$ and $\beta_{6}$ can be positive or negative and eventually the $\beta_{8}, \beta_{9}$ and $\beta_{10}$ mark should also be positive.

Now, after the model's approval phase, we are looking for the best way to estimate potential trade flows between countries in Region 2, which also includes individual effects for each trading country. In other words, it eliminates the heterogeneity bias.

According to similar studies, in order to select the appropriate method for estimating the model, the results of the F statistic and selecting between the fixed effect method and the random effects method are derived from the results of the Hausman statistics.

In this test, if $\mathrm{H} 0$ hypothesis rejected it shows there is a constant effect model and if $\mathrm{H} 0$ hypothesis accepted random effect model should be used for calculation. The results indicated as follows (Table 2).

According to the results of the Hausman test, we cannot rule out the zero hypotheses on the compatibility of the coefficients. Therefore, the random effects method is chosen as a more efficient method. Also, in terms of $\mathrm{R}^{2}$, the random effects method has more explanatory power and this is another confirmation of the choice of this method. The F-index also shows a much higher rate than the fixed effects method in the randomized effects method.

The results of this estimation show that the coefficient of gross domestic product variables, which indicates the size of the economies of the countries, is statistically significant and has a sign.

When GDP of importing country and GDP of exporting country increased one percent, the volume of trade will increase by 1.8 and 0.07 respectively. The smallness of this figure in relation to importing countries is indicative of the rivalry of these countries in the business.

In the case of F statistics (Table 3), the probability of accepting the H0 hypothesis is shown in parenthesis. The country's population variable is negative, which indicates that with one percent population increase in exporting countries their bilateral trade volume is reduced by $1.61 \%$ while the coefficient for the population of the importing country is $0.74 \%$. The negative coefficient of population in exporting countries suggests that the increase in population, increase

Table 2. Hausman test results.

\begin{tabular}{ccc}
\hline Estimation & Statistics & Test \\
\hline $0 / 00$ & $14 / 77$ & $\mathrm{X}^{2}$ statistics \\
\hline
\end{tabular}


Table 3. Results of gravity model estimation by random effects method

\begin{tabular}{cc}
\hline The explanatory variables & Coefficient \\
\hline Fixed value & $17.76(8.56)$ \\
The logarithm of GDP of exporting country & $1.87(17.36)$ \\
The logarithm of GDP of importing country & $0.061(4.85)$ \\
Population logarithm of the exporting country & $-1.61(-11.22)$ \\
Population logarithm of the importing country & $0.74(31.72)$ \\
Logarithm of the real exchange rate of the exporting country & $-0.091(-11.59)$ \\
Logarithm of the real exchange rate of the importing country & $-0.074(-7.912)$ \\
Logarithm of the distance between capitals of importing and exporting countries & $-0.13(-2.57)$ \\
Virtual boundary common variable & $0.62(11.44)$ \\
The virtual variable of common religion (cultural similarities) & $0.65(8.09)$ \\
Similarity variable cosinij & $1.55(11.21)$ \\
Number of observations & 100 \\
$\mathrm{R}^{2}$ & $\% 61$ \\
$\mathrm{~F}$ & 302.8
\end{tabular}

Source: Researcher's computing.

domestic production and consumption and they are less inclined to bilateral trade. The population positive coefficient in importing country states that the increase in population in these countries has not made them more intrusive and the demand for imports remains strong and it does not diminish.

The negative sign of exchange rate coefficients variable in exporting and importing countries indicates that the increase in exchange rate has led to a reduction in the volume of bilateral trade meanwhile the exchange rate in exporting countries is affected more.

The virtual variables of the common border and common religion between exporting and importing countries are 95\%, meaningful and have the expected positive sign. The effect of these two variables on bilateral trade will increase 0.86 and 0.91 percent among exporting countries respectively.

The formation of regional convergence becomes smoother when there are cultural, ethnic and linguistic commonalities among nations of a region. Distinguish the nations of a region from each other in the light of historical and a cultural tie, in turn, contributes to the growth of trade and other economic relations in the region. The existence of historical and cultural ties will also enhance the sense of identity and share common interests and destinies among member states in a regional order. Strengthening the sense of regional collective identity and the general belief in having shared destiny contributes to the formation of joint institutions in the region and facilitates the process of regional convergence.

As the statistics of Iraqi imports from Iran show, the distance variable is statistically significant and negatively as expected. The distance coefficient of -0.13 
percent indicates that countries with more distant countries tend to be less willing to enter into bilateral trade. However, given the small size of this coefficient and the presence of water \& land borders between the Caspian coastal countries and their adjacency, it can be argued that transport costs are not a serious obstacle to economic cooperation.

What links the countries of a regional geographic unit to each other is the existence of roads and networks. The member states of a regional geographic unit may be connected by sea or through land. The continuity of the member states of an open sea region is one of the ideal conditions for the transport of goods easier and cheaper with each other. The existence of a high sea between member states of a regional unit places them, in comparison with drought-bound countries, in a more regional context for regional convergence. Drought-affected countries are less likely to face major natural barriers. They can enjoy the benefits of geographical closeness for regional convergence.

Adding variable of angle cousin between exporting country $i$ and importing country $j$ to study the economies effects of the member states on the flow of trade show that this variable is of the expected magnitude and is statistically meaningful and has a significant positive effect on bilateral trade. Adding this variable increases 0.03 percent model's explanatory power.

The export potential of Iran to the countries of region 2 is calculated using the results of the model.

During the study period (Table 4), Iran had the highest exports in Iraq, Turkey, Russia, Azerbaijan and Armenia, respectively. Iran's greatest export potential is among the countries of Region 2 related to Iraq and the least potential is refer to Armenia.

The most unexploded export capacities of Iran, among the countries of region 2, belong to Iraq, Turkey, Azerbaijan, Russia and Armenia, respectively (32\%) and the least unused capacity to Armenia (the highest percentage of unused capacity in Iran is also in Azerbaijan (80.1\%) and the least unused capacity was allocated to Armenia (58.8\%). totally, Iran's export potential to countries in the region 2 amounted to 22/201 billion dollars which only 7/490 billion dollar is used. In terms of these four criteria (existing export, export potential, unused

Table 4. Non-oil export potential of Iran to the countries of the region (2011-2015) (Figures are in millions of dollars and percent).

\begin{tabular}{ccccc}
\hline Country & $\begin{array}{c}\text { Iran's available } \\
\text { export to region 2 } \\
\text { countries }\end{array}$ & $\begin{array}{c}\text { Iran potential } \\
\text { export to countries } \\
\text { region 2 }\end{array}$ & $\begin{array}{c}\text { Unused export } \\
\text { capacity }\end{array}$ & $\begin{array}{c}\text { Unused export } \\
\text { potential } \\
\text { percentage }\end{array}$ \\
\hline Turkey & 1194 & 5032 & 3837 & \\
Azerbaijan & 143 & 752 & 609 & 80.1 \\
Russia & 239 & 692 & 453 & 65.4 \\
Armenia & 84 & 204 & 120 & 58.8 \\
Iraq & 5830 & 15,521 & 9691 & 62.1 \\
\hline
\end{tabular}


capacity, and unused export potential percentage). In terms of these four criteria (export, export potential, unused export capacity and unused capacity of export potential), all five countries of Turkey, Azerbaijan, Russia, Armenia, Iraq are suitable alternatives for expanding trade cooperation.

\section{Conclusions and Suggestions}

Based on the study findings, it would be better for Iran to establish regionally convergent with countries that enjoy higher incomes (respectively, Russia, Turkey, Iraq, Azerbaijan, and Armenia) in terms of the income variable in importing countries (1.8).

Based on the coefficient of distance variable $(-0.13)$, it is better for Iran to establish a regional convergence with countries closer to it (Azerbaijan, Iraq, Turkey, Armenia, Russia)

Looking at the results of distance variable coefficient in importing country in order to sum up the trade preferences with the countries of this region, especially Russia and Turkey, due to the size of these coefficients and comparison of them, we conclude that the coefficient and effect of income variable on bilateral trade is far more than the distance variable, so the results of income variable are more important and the expansion of trade with Russia and Turkey, Iraq is recommended.

Looking at the figures, one can find that Iran's largest export potential is among the countries of region 2 to Iraq and the least potential belongs to Armenia. The most unexploited export capacity of Iran among the countries of Region 2 belongs to Iraq, Turkey, Azerbaijan, and Armenia. The highest percentage of unused capacity of the country is Azerbaijan (80.1\%); the least unused capacity belongs to Armenia (58.8\%). Overall, and Iran's export potential to countries in Region 2 was $\$ 22.13$ billion, of which only $\$ 4.790$ billion was used. In terms of these four criteria (available export, export potential, unused export capacity, and unused export capacity percentage), all five countries of Turkey, Azerbaijan, Russia, Armenia, Iraq are good alternatives for expanding trade cooperation.

The results showed that there is a high trade potential between Iran and any country in region 2. The expansion of trade with these countries and the creation of a trade blend could increase Iran's trade flows to these countries. In fact, with this process, Iran can take advantage of the static and dynamic benefits of trade creation.

\section{Conflicts of Interest}

The authors declare no conflicts of interest regarding the publication of this paper.

\section{References}

[1] Mesri Nejad, S. and Ebrahimi, S. (2006) The Effect of Trade Liberalization on Industry Performance in Developing Countries. Economic Reviews, 3, 133-115. 
[2] Mentantfar, Y. and Hossein, K. (2005) Assessing Non-Oil Exports and Their Impact on Economic Growth in Iran. Economic Journal, 5, 51-52.

[3] Azerbaijani, K. and Tayebi, S.K. (2001) Investigation of the Trade Potential between Iran and Ukraine: Applying a Gravity Model. Business Research Journal, 6, 21-80.

[4] Parvizi Kashkouli, F. and Nunjad, M. (2015) The Effect of Exchange Rate Volatility on Iranian Non-Oil Exports to Major Trading Countries. Strategic Policies Quarterly, 3, 99-122.

[5] (2015) ITC International Trade Centre.

[6] ICA (2015) Islamic Republic of Iran Customs Administration.

[7] Tinbergen, J. (1963) Shaping the World Economy. Twentieth Century Fund University Press, New York. https://doi.org/10.1002/tie.5060050113

[8] Linneman, H. (1966) An Econometric Study of International Trade Flows. North Holland, Amsterdam.

[9] Aitken, N.D. (1973) The Effect of the EEC and EFTA on European Trade: A Temporal Cross-Section Analysis. American Economic Review, 63, 881-892.

[10] Matyas, L. (1997) Proper Econometric Specification of the Gravity Model. The World Economy, 20, 363-366. https://doi.org/10.1111/1467-9701.00074

[11] Evenett, S.J. and Keller, W. (2002) On Theories Explaining the Success of the Gravity Equation. Journal of Political Economy, 110, 281-316.

https://doi.org/10.1086/338746

[12] Finestra, R. (1998) Advanced International Trade: Theory and Evidence.

[13] Anderson, J. and Wincoop, E. (2003) Gravity with Gravitas: A Solution to the Border Puzzle. NBER Working, 79-80. https://doi.org/10.1257/000282803321455214

[14] Melo, J. and Guillaumont, P. (2005) Has Distance Died? Evidence from a Panel Gravity Model. The World Bank Economic Review, 19, 99-120. https://doi.org/10.1093/wber/lhi004

[15] Rahman, M.M. (2003) A Panel Data Analysis of Bangladesh Trade the Gravity Model Approach. University of Sydney, Sydney.

[16] Lamotte, O. (2002) Trade Potential between Sugoslavia and EU, 7th EACES Conference.

[17] Harati, J., Amin, B. and Kahrazeh. S.M. (2015) A Study of the Factors Affecting Iran's Export. Journal of Economic Growth and Development Studies, 6, 29-46. 